\title{
Study on the Possibility of Applying the Tax Policy of the Russian Federation to Influence the Dynamics of the Exchange Rate
}

\author{
Alexander Ishkhanov \\ Department of World Economy and Management \\ Kuban State University \\ Krasnodar, Russia \\ E-mail: aviavi286@gmail.com
}

\author{
Elena Linkevich \\ Department of World Economy and Management \\ Kuban State University \\ Krasnodar, Russia \\ E-mail: alins@list.ru
}

\begin{abstract}
The article examines the Russian experience in the field of currency regulation and the instruments that affect the exchange rate of the Russian ruble in crisis conditions. It is justified that the dynamics of the Russian ruble exchange rate depends primarily on the influence of four factors: the state of the economy of the issuing country, state monetary and financial policies, price dynamics of international commodity markets, and instability of the global monetary and financial system. It was established that the Russian ruble exchange rate also depends on the volume of foreign currency purchases by the population, while a tendency for an increase in demand for foreign currency on the part of the population during the expectations of the devaluation of the national currency of the Russian Federation (RF) with a decrease in world oil prices was revealed. Based on an analysis of the currency policy of the Russian Federation, the authors come to the conclusion that curbing the weakening of the Russian ruble in the face of a decrease in the supply of foreign currency in the domestic market is carried out mainly through foreign exchange interventions and offer additional measures aimed at reducing demand on foreign currency through the introduction of tax instruments. Such measures will reduce the dependence of the ruble exchange rate on the volume of foreign currency inflows into the country, which will increase the efficiency of the Russian monetary policy and, as a consequence, the stability of the Russian economy to external adverse factors. In addition, six additional effects were revealed from the implementation of the proposed tax measures, which will strengthen the financial system of Russia. The proposed tax instruments can be applied in other countries, and the resulting increased demand for precious metals affects the global financial system up to its substantial transformation.
\end{abstract}

Keywords-exchange rate; exchange rate policy; exchange rate regime; demand for currency; foreign exchange intervention; tax policy; tax instruments

\section{INTRODUCTION}

In foreign economic relations, the exchange rate plays an important role. The dynamics of the exchange rate, the amplitude and frequency of its fluctuations are clear indicators of the country's economic and political stability.
However, as practice shows, one cannot underestimate the influence of external factors on the exchange rate.

Currently, the Russian Federation applies a floating exchange rate regime. It is assumed that this regime should act on the country's economy as a "built-in stabilizer" that allows it to quickly adapt to changing external conditions. However, according to many economists, this position is controversial. The insufficiency of applying the flexible exchange rate regime to smooth out the negative manifestations of external shocks in an open economy is substantiated in the works of many scientific economists (Corsetti et al. [1], Faltermeier et al. [2], Kliatskova and Mikkelsen [3], Korinek [4]; Rey [5]. In a study by Basu et al. [6], it is shown that many central banks, which formally adhere to a floating exchange rate policy, often pursue a policy of maintaining the national currency within a certain (comfortable) range.

According to the findings of the IMF annual review [7] monetary regulators in many countries increasingly prefer the use of less flexible or clearly defined exchange rate management regimes, as well as the use of foreign exchange interventions to ensure stability in national economies. Accordingly, the work of economist scientists aimed at studying the tools for influencing the exchange rate in modern conditions is of particular importance. Various methods of stabilizing the Russian ruble exchange rate were considered in the works of E. Gilenko [8], A. Kiyutsevskaya [9], M. Sulimierska [10], S. Blinov [11], N. Chutasripanich and J. Yetman [12].

The article examines the currency regulation tools used in Russia. It is proposed to introduce additional measures based on the use of the tax policy of the Russian Federation that can stabilize the Russian ruble by managing the population's demand for foreign currency.

\section{A RETROSPECTIVE REVIEW OF RUSSIAN EXPERIENCE IN STABILIZING THE EXCHANGE RATE}

The policy of managing the exchange rate of the Russian ruble has developed and improved in the difficult conditions of the formation of a market economy, consistent 
liberalization of foreign trade, and stimulation of the development of the export potential of the country's oil and gas complex. The shock nature of the reforms carried out in the 90 s of the last century predetermined a decrease in controllability of the country's economy. The liberalization of foreign trade and currency regimes in the absence of an effective system of currency control de-stabilized the currency markets. In 1991, the first law on currency regulation was adopted in the context of the development of a market economy [13], which determined only the main directions of monetary policy. The law established the general principles of conducting currency transactions in the domestic turnover of the country and in international settlements, the main areas of currency control, the rights and obligations of individuals and legal entities, as well as measures of responsibility for violation of currency legislation. Regulatory acts in the field of currency regulation established certain restrictions on the export of foreign currency, the procedure for the mandatory sale of part of export earnings, and the permissive procedure for the sale of goods for foreign currency in the Russian Federation.

Experience has shown that, in general, the currency legislation adopted at that time could not ensure the stability of the Russian ruble exchange rate and required reform. It was very difficult to prevent the outflow of capital abroad and to ensure the repatriation of the foreign exchange earnings of exporters to Russia in the absence of an effective system of currency control. To avoid currency control, legislative gaps were used.

Currency interventions were recognized as the most effective tool for stabilizing the exchange rate of the Russian ruble, however, the available foreign exchange reserves were not enough to restrain the devaluation of the monetary unit of the Russian Federation. In 1992, the Central Bank of the Russian Federation was able to provide only 1055.9 million US dollars for foreign exchange interventions. The exchange rate of the Russian currency during the year decreased from 110 to 414.5 rubles per 1 US dollar [14].

The transformation of the system of currency regulation and control took place under the conditions of a deep economic crisis. The year 1993 was characterized by a decrease in oil prices, which exacerbated the situation. Therefore, the main directions of the policy in the field of currency and financial regulation required additional measures necessary to reduce the severity of the manifestation of crisis phenomena in the country's economy. In 1993, a policy was pursued aimed at improving the effectiveness of the currency control system. In addition, the Central Bank of the Russian Federation officially prohibited the use of foreign currencies in domestic payment transactions. A ban was also imposed on the use of freely convertible currency when selling goods manufactured in Russia on the domestic market. It was assumed that these measures will stop the process of dollarization in the economy and reduce domestic demand for the US dollar, thereby contributing to the stabilization of the Russian ruble. Nevertheless, during the year, the Russian ruble depreciated against the US dollar by 3 times [15]. In conditions of economic instability, high inflation and loss of confidence in the national currency, the US dollar continued to enjoy high demand from the population. The US currency has acquired a kind of unofficial status of a highly liquid security that is constantly growing in price and is a means of protecting savings from inflation. In the future, high demand for the US dollar by the population continued to persist (even in the period from 1995 to 1997, when the Russian ruble became more stable).

The policy regarding foreign exchange reserves at that time was built in accordance with international practice. The adequacy of the country's foreign exchange reserves was determined by an indicator characterizing the degree of coverage of the average monthly import costs. At the end of 1993, the accumulated foreign exchange reserves were sufficient to ensure imports for 1.4 months, which was considered acceptable [15].

Regulation of the ruble exchange rate through currency interventions allowed slowing down the devaluation processes from 1995 to 1997, in the conditions of a favorable price situation on the world oil market. However, already at the end of 1997, the situation worsened. As practice has shown, in 1998, with the complication of the external economic situation for Russia due to the decrease in world oil prices, the measures taken were not enough. The policy pursued by the Central Bank of the Russian Federation to unilaterally peg the exchange rate of the Russian ruble to the US dollar has led to additional regulatory difficulties, as it has led to unreasonable appreciation of the national currency against the currencies of the main West European trading partners, which made it difficult to overcome the crisis in financial sphere.

Already in early 1998, for many participants in the currency and financial market, it became apparent that the measures taken could not ensure the stability of the Russian currency for a long time. Demand for the US dollar in Russia increased significantly due to the massive transfer of ruble bank deposits of the population into foreign currency in cash or foreign currency deposits.

The situation in the foreign exchange market was aggravated by the crisis in the public sector. The increase in government debt over the past five years has led to a destabilization of the public finance system. By the end of the first half of 1998, the cost of servicing domestic debt accounted for more than $30 \%$ of budget expenditures [16].

The Central Bank of the Russian Federation continued to actively use the use of interventions to support the ruble exchange rate. From January 1 to August 17, 1998 (in the pre-default period), almost 13 billion US dollars were sold in the domestic foreign exchange market, which amounted to about $75 \%$ of the country's foreign exchange reserves and exceeded net foreign currency by more than $\$ 100$ million reserves at the beginning of the year [16]. The replenishment of foreign exchange reserves through IMF loans has created additional problems associated with the buildup of external debt obligations.

After the default announced on August 17, 1998, there was an abandonment of the practice of placing high-yield 
government short-term bonds (T-bills) in the domestic market, which led to the overflow of ruble money supply from T-bills into dollars, thereby creating an already high demand for U.S. dollar. As a result, the Central Bank of the Russian Federation was forced to abandon support for the ruble against the US dollar, however, in order to prevent accelerated devaluation of the national currency, active currency interventions continued. So, in the second half of August, about 2.5 billion US dollars were sold in the domestic foreign exchange market. However, these measures could not ensure a slowdown in the devaluation of the Russian ruble. At the beginning of September 1998, the Russian currency depreciated from 6.29 to 10 rubles per 1 US dollar, after which the Central Bank of the Russian Federation refused to actively conduct foreign exchange interventions. As a result, by the end of 1998, the Russian ruble depreciated against the US dollar by $230 \%$ (up to 20.65 rubles per US dollar) [16]. Thus, active foreign exchange interventions to maintain a balance of supply and demand of foreign currency in the domestic market were not effective, and provided only a delay in the devaluation of the ruble. As a result of the sharp devaluation, the ruble exchange rate, formed in the face of negative expectations from the participants of the foreign exchange market and the outflow of capital from the country, turned out to be significantly underestimated.

In crisis conditions, the regulatory authorities of the Russian Federation applied stabilization methods for the Russian ruble exchange rate, corresponding to the current state of the monetary and financial sphere and the national economy. The transition in 1999 to the regime of a controlled floating exchange rate assumed the application of regulatory measures only to smooth out sharp fluctuations in the exchange rate of the Russian ruble.

As one of the most significant tools for regulating the exchange rate, currency interventions were still considered. Moreover, the subsequent improvement in the dynamics of the Russian foreign exchange market was largely due to the introduction of additional measures in the field of foreign exchange regulation and foreign exchange control. According to experts, the supply of foreign exchange earnings in the Russian foreign exchange market increased by $\$ 15.5$ billion compared with 1998 [17]. An important role was played by a change in the order and an increase in the mandatory norm for the sale of export foreign exchange earnings. A requirement was also introduced for the compulsory sale of advance payments returned from abroad on import contracts. In order to prevent capital outflows abroad, a standard was established for credit organizations to form reserves for operations with residents of offshore zones. A special procedure for correspondent relations with offshore banks was also adopted based on the rating system of foreign banks. These measures have provided a significant reduction in the volume of currency transferred to offshore [17]. In addition, in March 1999, the Central Bank of the Russian Federation imposed a mandatory requirement to open $100 \%$ of the amount of funds transferred to purchase foreign currency to pay for imported goods at authorized banks by resident companies in ruble deposits. Import into the territory of Russia. This measure has significantly limited the ability to transfer foreign currency abroad under fictitious import contracts. As a result, the amount of advance transfers abroad was significantly reduced. According to experts, at the beginning of 1999 the share of advances in the total amount of payment for import supplies was $50 \%$, and at the end - not more than $15 \%$ [17].

A temporary ban was also introduced for non-residents on the conversion of ruble funds placed on correspondent accounts of foreign banks opened with authorized commercial banks of Russia [17].

Overcoming the consequences of the monetary and financial crisis made it possible to abolish many additional currency restrictions. However, when significant changes were made to the currency legislation of the Russian Federation, conditions were met that limited the ability to transfer foreign currency funds abroad.

The increase in world oil prices from January 2000 to August 2008 ensured the stability of the Russian ruble, and also allowed a significant increase in foreign exchange reserves. Over the indicated period, net foreign exchange reserves increased 68.6 times (from 8.5 to 582.7 billion US dollars) [18]. In addition, the stability of the Russian ruble predetermined an increase in public confidence in the national currency and a decrease in demand for foreign currencies. As can be seen in "Fig. 1", the share of deposits in foreign currencies (most of which was the US dollar) has consistently declined from 2000 to mid-2008.

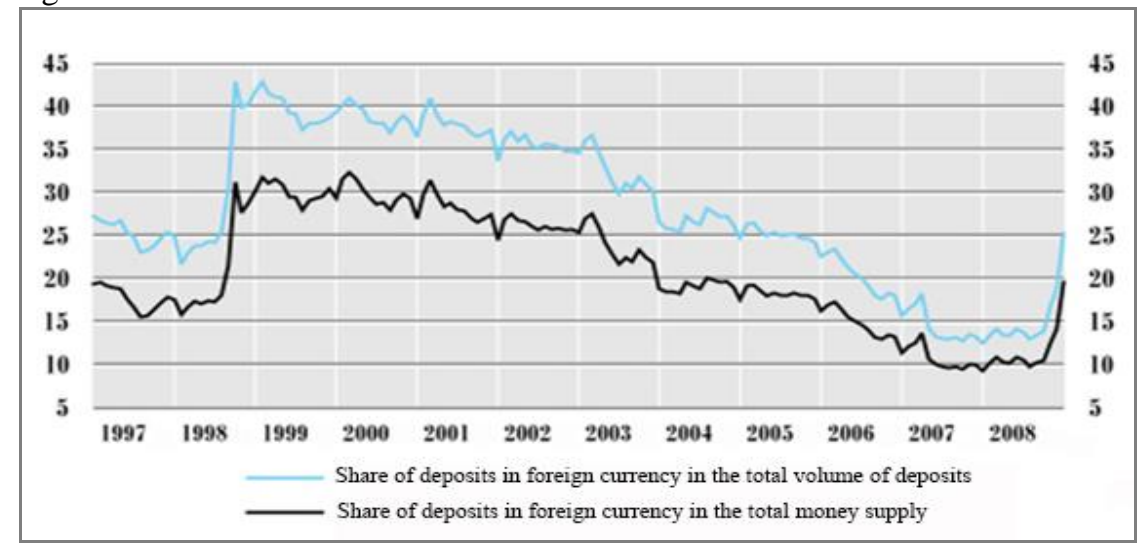

Fig. 1. Dollarization of deposits, \% [18]. 
In the second half of 2008, a decrease in world oil prices predetermined a reduction in revenues to the Russian foreign exchange market, which caused a booming demand from the population ("Fig. 2").

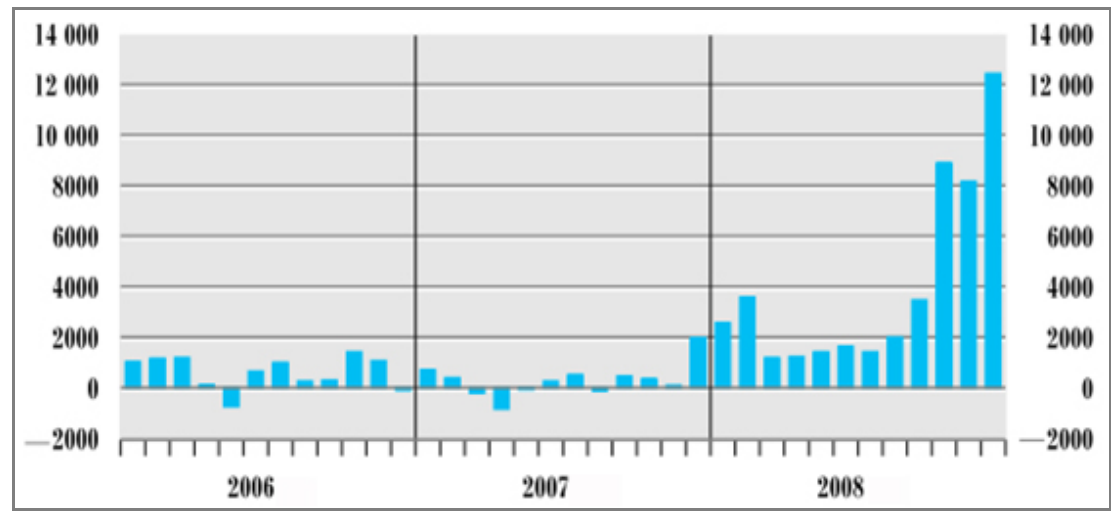

Fig. 2. Net sales of foreign currency to individuals through exchange offices (million US dollars) [18].

The volume of foreign currency purchases by the population increased by $81.3 \%$ compared to 2007 . In this situation, the Bank of Russia pursued a policy of stabilizing the exchange rate of the Russian ruble by conducting currency interventions in the domestic market. The total net sales of foreign currency from August to December 2008 amounted to more than $\$ 168$ billion. At the same time, a significant share was the sale of currency to the population. At the end of the year, net demand from the population amounted to 37.3 billion US dollars [18]. In 2008, the growth rate of funds on deposits in dollar terms amounted to $140.2 \%$, and in 2009 , already in the face of an improvement in the dynamics of the world oil market, another $16.5 \%$ compared to the previous year ("Fig. 3"):

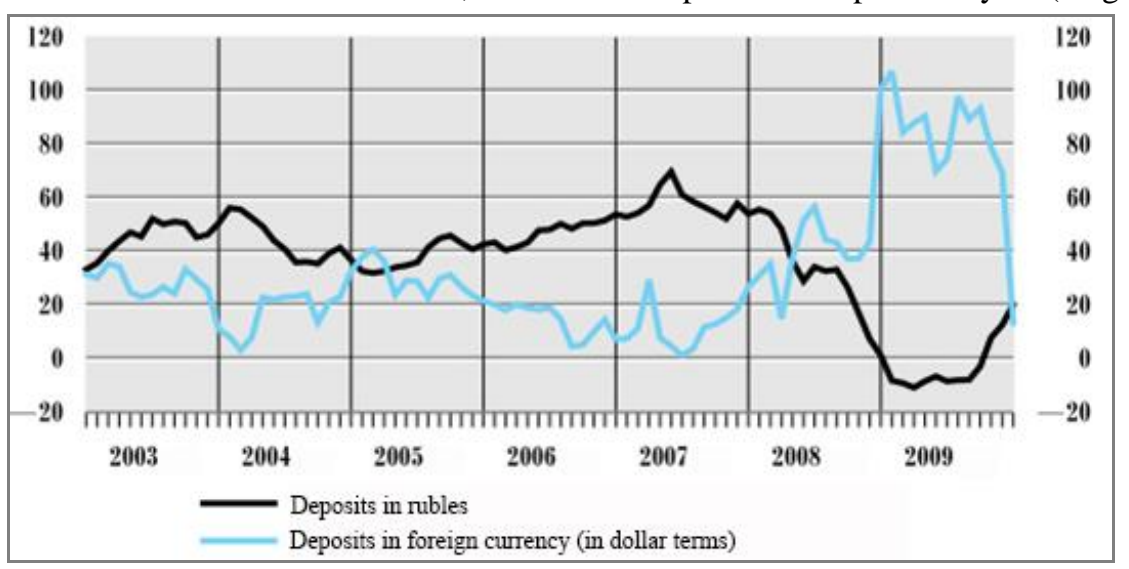

Fig. 3. Deposits in rubles and in foreign currency (interest growth to the corresponding date of the previous year) [19].

According to the results of 2008, the US dollar strengthened against the Russian ruble by $19.7 \%$. In the future, in connection with the preservation of foreign economic conditions that led to the further devaluation of the ruble, the Bank of Russia was forced to continue large-scale foreign exchange interventions in the domestic market. Demand for foreign currency in the Russian Federation decreased only in 2009. The reason was the loss of confidence in the US dollar due to the crisis in the economy and finance of the issuing country. The total volume of net sales of foreign currency by the results of 2009 significantly decreased and amounted to 39.6 billion US dollars. The devaluation of the Russian currency slowed down. In 2009, the US dollar strengthened against the ruble by only $2.9 \%$ [19]. Favorable for Russia, the dynamics of world oil prices ensured the stability of the ruble exchange rate from 2009 to 2013. During the indicated period, the purchase of foreign currency by the Bank of Russia in the domestic market exceeded sales, which ensured the growth of foreign exchange reserves. However, in 2014 the situation changed. A consistent decline in oil prices predetermined the devaluation of the Russian currency ("Fig. 4" and "Fig. 5").

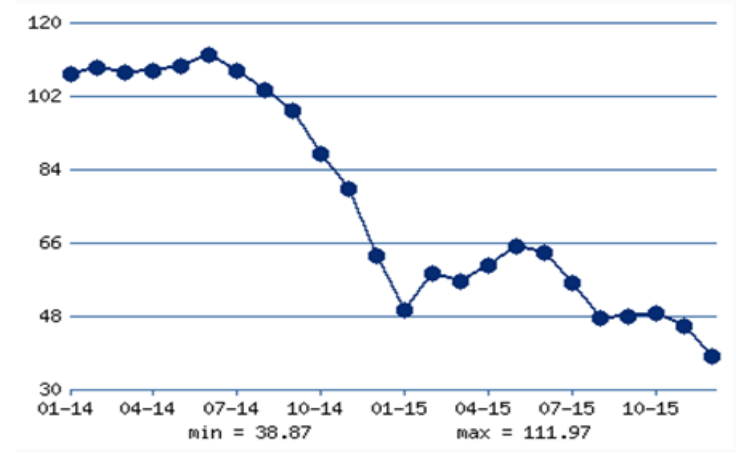

Fig. 4. Dynamics of world oil prices Grades Brent (IPE), USD / barrel [20]. 


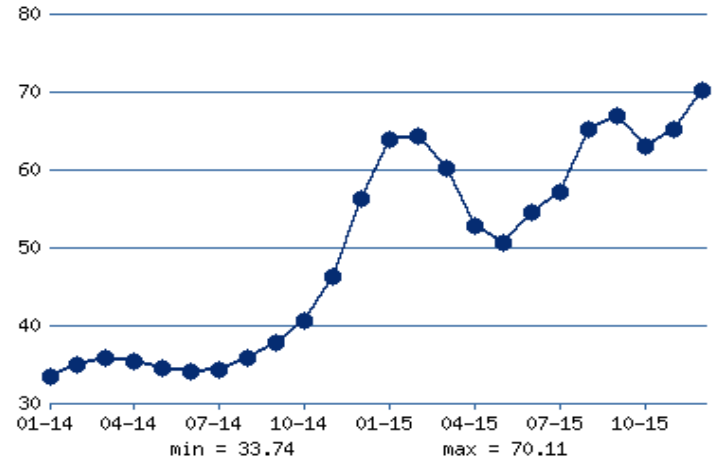

Fig. 5. The ruble exchange rate of the RussianFederation against the US dollar [20].

Since 2014, in connection with the introduction of antiRussian sanctions by the United States, the European Union and some other countries, the situation in the Russian financial system continued to worsen. The restriction of access to international capital markets to the largest Russian banks and companies was one of the reasons for the significant depreciation of the Russian ruble. In such circumstances, the US dollar began to enjoy increased demand from the population, which further complicated the situation. Chairman of the Bank of Russia E.S. In her speech following a meeting of the Board of Directors on December 11, 2014, Nabiullina stated that the weakening of the Russian ruble as a whole since the beginning of the year amounted to $49 \%$, while only due to rush demand from the population, the rate fell by $8-10$ percentage points [21]. Compared to 2013 , the volume of purchases by the population of cash foreign currency in 2014 increased by more than $49.6 \%$, amounting to 71.9 billion US dollars. Net demand for foreign currency for the year increased by 2.8 times and amounted to 46.3 billion US dollars [22]. In 2015, the demand for foreign currency decreased [23], however, the trend of preferences for storing savings in foreign currency continued for another 2-3 years.

Currently, the Bank of Russia adheres to a floating exchange rate policy, which involves a minimum of intervention in regulating the dynamics of the foreign exchange market. At the same time, a complete rejection of the impact on the exchange rate is not provided. Currency interventions continue to be considered the most effective tool for stabilizing the Russian ruble, the conduct of which is allowed in case of threats to financial stability in the Russian Federation. However, we believe that in the face of the threat of devaluation of the national currency, these measures will not be enough. Additional measures are needed to ensure a decrease in the demand for foreign currency on the part of individuals. One of such measures may be tax incentives for refusing to buy foreign currency.

\section{Proposed TAX MEASURES ON THE EXChange Rate OF THE RUSSIAN RUBLE}

The policy in the field of exchange rate formation should be carried out taking into account Russian specifics and take into account the impact of population demand on the dynamics of the foreign exchange market. It should be borne in mind that when preconditions arise for the depreciation of the Russian ruble in Russia, the demand for foreign currency (mainly the US dollar) from individuals will almost always increase significantly. The rush demand arises in the conditions of a decrease in the supply of foreign currency in the domestic market of the country and leads to an even greater weakening of the Russian ruble. At the same time, the weakening of the Russian ruble is restrained mainly due to foreign exchange interventions. However, we believe that the ruble can be supported by curbing demand, which can be achieved through the use of tax instruments. For this, it is necessary to amend the tax legislation of the Russian Federation four changes:

- Introduce taxation of VAT on the sale and purchase of foreign currency for Russian rubles.

- Cancel VAT on the purchase of physical precious metals.

- Introduce a tax on the purchase of foreign currency with the provision for the possibility of prompt changes in its rate.

- Introduce tax on foreign currency accounts.

Currently, the purchase of foreign currency is not subject to VAT, while the purchase of precious metals is subject to VAT in full (Article 149 of the Tax Code of the Russian Federation) [24].

Obviously, the 1st and 2nd changes will redirect ruble liquidity from the foreign exchange market to the precious metals market. This will significantly reduce the demand for US dollars and will additionally create an obstacle to the export of Russian capital abroad. However, tax incentives may not be enough to buy gold instead of dollars for investment incentives. It is necessary to create conditions for the purchase, sale and storage of precious metals. This can be done through the creation of state depositories in large cities of Russia, through which it will be possible to buy, sell and store deposited precious metals for a symbolic commission. At the same time, a personal certificate of ownership for a certain volume of one or another precious metal will be issued.

As for the 3rd change, such a tax previously existed in Russia [25]. Then his rate was $1 \%$. Now it is proposed to introduce a floating rate from $0 \%$ to $30 \%$, and to regulate it in accordance with the recommendations of the Bank of Russia. The introduction of such a tax will also reduce the investment attractiveness of foreign currencies.

The 4th change will make it unprofitable to concentrate assets on foreign currency accounts. Even a small rate can make currency deposits unprofitable. Entering the indicated tax will stimulate the transfer of foreign currency accounts into ruble or precious metals. This will be expressed in an additional offer of foreign currency in the Russian foreign exchange market and, as a result, will have a positive impact on the stability of the Russian ruble. 
purchase of precious metals (primarily gold) on world markets will be required. An increase in demand for gold in world markets will lead to a constant trend of increasing its world price. If Russia begins this process first, then at the expense of its citizens, a large share of world gold reserves will soon be concentrated in Russia, moreover, purchased before the global price increase. Already in the short term on the world markets with high probability there will be an excessive demand for gold. And since gold is traded in US dollars, we can predict the redistribution of the world dollar mass in favor of gold. This process, as a result, will lead to the collapse of the US dollar and create prospects for the Chinese yuan and the Russian ruble as new world reserve currencies.

- The world monetary system (MVS) in the coming years expects significant updates. The prerequisites for changes in the existing monetary order were studied in detail in our article "Global monetary system: from past to future" [26]. The tax methods of regulating and stabilizing the exchange rate proposed in the article may become the impetus for the process of reforming the MVS, and not only Russia, but also China, is interested in this.

\section{CONCLUSION}

For the effective regulation of monetary and financial relations within the framework of the activities of state financial bodies, it is necessary to conduct a policy that ensures the stabilization of exchange rates. As you know, many factors influence the exchange rate of the national currency, the most significant of which are: inflow or outflow of capital, state of foreign trade balance, volumes of official foreign exchange reserves, servicing of external debt, expectations of economic entities, domestic demand for foreign currency from the population. The sharp fluctuations in the exchange rate not only worsen the conditions of foreign trade, but also negatively affect the state of the national economy.

An analysis of the experience of the Russian Federation in the field of currency regulation allows us to conclude that various tools were actively used in Russian practice to ensure the containment of capital outflows abroad, as well as the ability to compensate for the shortage of currency in the domestic market in the context of a reduction in its supply. At the same time, measures taken over a long period of time to prevent the accumulation of currency imbalances have been tightened in some cases when there is a threat or when it is necessary to overcome the currency crisis. Also, in times of crisis or growing imbalances, additional instruments of currency regulation were often introduced, which were subsequently canceled.

However, it should be taken into account that the effectiveness of the impact on the dynamics of exchange rates is largely determined by the effectiveness of the regulatory system taking into account country specifics. The behavior of economic agents is largely determined by the expected dynamics of the foreign exchange market. precious metals, a situation of acute shortage of precious metals in Russia is likely. Therefore, the 
University of Sussex Business School, Working Paper Series 5112 2012 [online]. URL: https://ideas.repec.org/p/sus/susewp/5112.html

Information on future changes in exchange rates has a significant impact on decisions made by legal entities and individuals regarding the purchase or sale of foreign currency.

We propose to supplement the system of measures to stabilize the exchange rate of the Russian ruble with instruments of tax regulation. Changes in the tax legislation of the Russian Federation will not only increase the effectiveness of the Russian monetary policy, but also actively influence foreign trade, as well as regulate the redistribution of capital. Through tax policy, the influence of external adverse factors on the country's economy can be significantly reduced. Implementation of the proposed tax instrument will provide additional positive effects for the Russian financial system. These tax instruments can be used not only in Russia but also in other countries, which will not only protect their national economies in the conditions of instability of the world economy, but also accelerate the establishment of a new currency order.

\section{REFERENCES}

[1] G. Corsetti, K. Kuester, G.J. Muller, "The Case for Flexible Exchange Rates in a Great Recession", Cambridge University, 2016, [online]. URL:

https://www.repository.cam.ac.uk/bitstream/handle/1810/257141/cwp e1644.pdf? sequence $=1$ \&isAllowed $=y$

[2] J. Faltermeier, R. Lama, J. Medina, "Foreign Exchange Intervention and the Dutch Disease", International Monetary Fund, IMF Working Paper, WP/17/70, 2017 [online].

[3] URL:

https://www.imf.org/ /media/Files/Publications/WP/2017/wp1770.as $\mathrm{hx}$

[4] T. Kliatskova, U. Mikkelsen, "Floating with a Load of FX Debt?", International Monetary Fund, WP/15/284, 2015, [online]. URL: https://www.imf.org/external/pubs/ft/wp/2015/wp15284.pdf

[5] A. Korinek, "The New Economics of Capital Controls Imposed for Prudential Reasons", International Monetary Fund, WP/11/298, 2011 [online]. https://www.imf.org/external/pubs/ft/wp/2011/wp11298.pdf

[6] H. Rey, "Dilemma not trilemma: the global financial cycle and monetary policy independence", National Bureau of Economic Research, Working Paper 21162, 2015, [online]. URL: https://www.nber.org/papers/w21162.pdf

[7] S. Basu, A. Ghosh, J. Ostry, P. Winant, "Managing Capital Outflows: The Role of Foreign Exchange Intervention", The Society for Economics Dynamics, 2016, [online]. URL: https://economicdynamics.org/meetpapers/2016/paper_756.pdf

[8] Annual Report on Exchange Arrangements and Exchange Restrictions, International Monetary Fund, Washington, 2017 [online]. URL: $\quad$ https://www.imf.org/en/Publications/Annual-Report-onExchange-Arrangements-and-Exchange-

Restrictions/Issues/2018/08/10/Annual-Report-on-ExchangeArrangements-and-Exchange-Restrictions-2017-44930

[9] E.V. Gilenko, "The "Sudden" Transition to the Free Floating Exchange Rate Regime in Russia in 2014", Journal of Reviews on Global Economics, 6, pp.181-192, 2017. [online]. URL: https://www.scopus.com/sourceid/21100817618?origin=resultslist

[10] A. Kiyutsevskaya, "Floating Exchange Rate of the Russian Ruble: Myth or Reality?", Voprosy Economiki, vol. 2. pp. 50-67, 2014. [online]. URL: https://ideas.repec.org/a/nos/voprec/2014-02-3.html

[11] M. Sulimierska, "After Ten Years of the Russian Crisis, How Might IMF intervention Be Evaluated?", Department of Economics,
[12] S. Blinov, "How to stabilize the Currency exchange rate", MPRA Paper 70650, University Library of Munich, Germany, 2016 [online]. URL: https://ideas.repec.org/p/pra/mprapa/70650.html

[13] N. Chutasripanich, J. Yetman, Foreign exchange intervention strategies and effectiveness, Bank for International Settlements, BIS Working Papers № 499, $36 \mathrm{p}, 2015$ [online]. URL: https://www.bis.org/publ/work499.pdf

[14] Law of the USSR of 01.03.1991 No. 1982-1 "On Currency Regulation"

[15] Department of Research, Information and Statistics of the Central Bank of the Russian Federation, 1992 Annual Report, Moscow, 1993. [online]. http://www.cbr.ru/Collection/Collection/File/7821/ar_1992.pdf

[16] Central Bank of the Russian Federation, Annual Report 1993 Moscow, $1994 . \quad$ [online]. URL: http://www.cbr.ru/Collection/Collection/File/7820/ar_1993.pdf

[17] Central Bank of the Russian Federation, 1998 Annual Report Moscow, $1999 . \quad$ [online]. URL http://www.cbr.ru/Collection/Collection/File/7815/ar_1998.pdf

[18] Central Bank of the Russian Federation, Annual Report 1999 Moscow, 2000.2 [online]. URL http://www.cbr.ru/Collection/Collection/File/7814/ar_1999.pdf

[19] Central Bank of the Russian Federation, Annual Report 2008 , Moscow, 2009.2 [online]. http://www.cbr.ru/Collection/Collection/File/7805/ar_2008.pdf

[20] Central Bank of the Russian Federation, Annual Report 2009 , Moscow, 2010.2 [online]. URL http://www.cbr.ru/Collection/Collection/File/7804/ar_2009.pdf

[21] Intercontinental Exchange - ICE. London. [online]. URL: //http://www.ereport.ru/results.php

[22] Statement by the Chairman of the Bank of Russia E.S. Nabiullina following the meeting of the Board of Directors on December 11, 2014 [online]. URL: http://www.cbr.ru/press/st/press_centre/Nabiullina_11122014/

[23] Bank of Russia, Bank of Russia Annual Report for 2014, Moscow, $2015 . \quad$ [online]. URL http://www.cbr.ru/Collection/Collection/File/7799/ar_2014.pdf

[24] Bank of Russia, Bank of Russia Annual Report 2015, Moscow, 2016 [online]. http://www.cbr.ru/Collection/Collection/File/7798/ar_2015.pdf

[25] Tax Code of the Russian Federation. The current edition of the Tax Code [online]. URL: http://www.consultant.ru/document/cons_doc_LAW_28165/c8ebcedc 9ddce9d959d6c520c3b0d602f71e8e12/

[26] Federal Law "On the Tax on the Purchase of Foreign Currency and Payment Documents Expressed in Foreign Currency" (No. 120-FZ of 07/21/1997) [online]. URL: http://www.consultant.ru/cons/cgi/online.cgi?req=doc\&base=LAW\& $\mathrm{n}=19368 \& \mathrm{fld}=134 \& \mathrm{dst}=1000000001,0 \& \mathrm{rnd}=0.6686606697659867 \#$ 017636887697801096

[27] A.Y. Arkhipov, A.V. Ishkhanov, E.F Linkevich "Global monetary system: from past to future", Life Science Journal. 2014. vol. 116 N $\begin{array}{llll}11 . & \text { pp. } & \text { [online]. } & \text { URL: }\end{array}$ http://www.lifesciencesite.com/lsj/life1111/096_25996life111114_54 8_553.pdf. 